\title{
ANALISA POWER OF HYDROGEN DAN KESADAHAN FEED WATERBOILER GUNA MENINGKATKAN EFISIENSI BOILER DI PT. DJARUM KUDUS
}

\author{
Herry Widodo $^{1^{*}}$, Ryan Saputra ${ }^{1}$, Puryadi ${ }^{1}$ \\ ${ }^{1}$ Program studi Teknika, Politeknik Bumi Akpelni \\ Jl. Pawiyatan Luhur II/17, Bendan Dhuwur, Semarang \\ *Email: heri.widodo@akpelni.ac.id
}

\begin{abstract}
Abstrak
Pengolahan air umpan boiler digunakan sebagai umpan boiler. Penelitian ini bertujuan mengetahui nilai PH,Kesadahan, dan total disolved solve pada airumpan boiler dengan media air sumur di PT. DJARUM KUDUS, dengan acuan standar menurut SOC PT.Djarum Kudus. Metode penelitian penulis gunakan yaitu analisa kuantitatif. Metode analisa kuantitatif menganalisa sampel air sumur di laboratorium kimia dengan titrasi sehingga didapatkan konsentrasi Ca,Mg yang terlarut dalam sampel, sampel di ambil dari sumur 1 dan sumur 2 di PT.DJARUM Kudus. Serta analisa PH dan Kesadahan. Hasil penelitian menunjukkan : air umpan boiler sumur 1 dengan PH 9,40, dan kesadahan 2 ppm, dan air umpan boiler pada sumur 2 dengan PH 8,90, dan Kesadahan 1,8 ppm. didapat dari penelitian tersebut PH dari Sumur 1 tidak memenuhi standart yaitu 9,40 PH. Karena tingginya pH bisa mengakibatkan korosi pada dinding pipa boiler mengganggu transfer panas dan memperpendek umur alat. Sedangkan hasil analisa kesadahan pada air sumur 1 dan sumur 2 memenuhi SOC PT. Djarum Kudus.
\end{abstract}

Kata Kunci : Boiler, PH,dan Kekerasan Air

\section{PENDAHULUAN}

Pada era globalisasi ini, kebutuhan manusia semakin bertambah dan beragam oleh karena itu, harus selalu didukung oleh perkembangan teknologi guna memenuhi kebutuhan tersebut. Demikian juga dalam penerapan boiler ini hampir digunakan dalam semua bidang khususnya bidang industri.

Pada dasarnya boiler adalah alat yang berfungsi untuk memanaskan air dengan menggunakan panas dari hasil pembakaran bahan bakar, panas hasil pembakaran selanjutnya dialirkan ke air sehingga menghasilkan steam (uap air yang memiliki temperatur tinggi).

PT. Djarum merupakan industri pembuatan rokok, boiler termasuk sarana pendukung dalam proses produksinya. Unit ini berfungsi sebagai penyedia uap untuk proses pengolahan tembakau dancengkeh. Untuk menyediakan hasil produksi yang baik sesuai dengan kebutuhan konsumen diperlukan saranapendukung yang memadai seperti:permesinan yang baik dan sumber daya manusia yang profesional, disiplin serta terampil di setiap bidangnya.

Demi menjaga kualitas produksi yang baik tentu diperlukan pengolahan dan perbaikan rutin pada sistempengolahan air pada boiler yang sesuai dengan manual book. Pengolahan yang dilakukan antara lain:

Pengendalian blowdown padaboiler, regenerasi proses water softener, (water softener adalah suatu alat yang digunakan untuk mengurangi bahan - bahan mineral $\mathrm{Ca}$ dan $\mathrm{Mg}$ yang terdapat dalam air sumur kesadahan) dan pemeriksaan kualitas air Power ofHydrogen, dan kesadahan untuk air umpan boiler.

Pengolahan air umpan boiler ini dilakukan untuk mencegah penurunan kualitas air, terjadinya korosi di dalampipa boiler air dan menghambat transfer panas, produksi uap yang mengakibatkan semua unit berjalan tidak maksimal.

Oleh karena itu kinerja sistem pengolahan air pada boiler harus diperhatikan dengan tujuan agar boiler memiliki usia kerja yang optimal. Hal ini dikarenakan air boiler menjadi faktor paling 
utama sebagai penyebab terjadinya korosi pada pipa-pipa boiler. Dan korosi,menjadi perusak yang paling utama terhadap boiler. Kualitas air boiler ditunjukan oleh berbagai parameter yang terukur yang harus berada pada nilai tertentu untuk dapat menghasilkan kualitas air boiler berada dalam kondisi yang baik.

Boiler umumnya menggunakan air sebagai media, air yang dipanaskan di dalam boiler menghasilkan uap air yang di salurkan ke proses produksi .

Pemanas bersumber dari pembakaran bahan bakar padat seperti batu bara, yang dibantu dengan oksigen dalam proses pembakaran diruang bakar sehingga memanaskan media air yang ada di dalam pipa-pipa tersebut. Panas tersebut dapat berubah menjadi uap untukproses produksi.

Uap adalah hasil dari produksi boiler yang berasal dari air, di dalam boiler yang telah memperoleh kalor atau panas dari pembakaran bahan bakar pada ruang bakar boiler terjadi transfer panas. Efisiensi panas yang dihasilkan salah satunya tergantung dari kualitas air dan bahan bakar (batu bara)

\section{LANDASAN TEORI}

Yohana E dan Askhabulyamin (2009), boiler adalah suatu alat berbentuk bejana tertutup yang digunakan untuk menghasilkan steam. Steam diperoleh dengan memanaskan bejana yang berisi air dengan bahan bakar. Bahan bakar boiler yang di pakai di PT. Djarum bahan bakar solar, sehingga menghasilkan energi yang stabil.

Jenis-jenis Boiler :

\section{A. Boiler Pipa Api}

Boiler pipa api pada dasarnya terdiri dari sebuah tangki yang berbentuk silinder atau sebuah bejana yang berisi air yang mempunyai sejumlah pipa yang merupakan aliran gas panas, dan gas panas tersebut dipindahkan ke dalam tangki / bejana yang berisi air. Gas panas diperoleh dari energi panas yang dihasilkan dari pembakaran bahan bakar. Pada sistem boiler ini, air bertekanan tinggi di tempatkan di sisi luar pipa api. Masalah yang berkaitan dengan boiler pipa api adalah akibat yang timbul bila terjadi kerusakan besar pada pipa.

\section{B. Boiler Pipa Air}

Boiler ini kebalikan dari boiler pipa api dimana air mengalir di dalam pipa sedangkan gas panas beredar di sekitar pipa itu. Jadi bidang pemanas boiler terdapat pada bidang luar pipa dan bidang yang dipanaskan terdapat di dalam pipa. Boiler, uap inimempunyai tekanan dan temperatur kerja yang tinggi, sehingga digunakan pada pembangkit tenaga uap yang besar.

Dalam sistem perawatan air yang baik, maka terlebih dahulu mengetahui syarat air boiler yang memenuhi standar untuk proses produksi, antara lain :

Penampungan Air

Dalam boiler terdapat beberapa tempat penampungan air, air dari sumur dipompa lalu ditampung disuatu bak besar, dari bak ini feed water pump akan bekerja sesuaikebutuhan air yang diperlukan boiler. Dari bak air press tank dan softener baru masuk ke feed water tank, air dalam feed water tank inilah yang akan masuk ke dalam boiler dengan temperatur 80-90 .

Syarat-syarat air pada boiler yang dipakai :

Air Pengisi $\quad: \mathrm{pH}\left(25^{\circ} \mathrm{C}\right) \quad: 7,5-10$

Hardness $\mathrm{CaCO}_{3} \quad: \max 3 \mathrm{ppm}$

Air Boiler $\quad$ : $\quad$ PH $\left(25^{\circ} \mathrm{C}\right): 10,5-$ 11,5

Hardnes : $\max 3$ ppm. Bebas dari kotoran Sehingga air boiler harus diperiksa setiap hari meliputi : Kadar Salinitas (garam), Kadar Chlorida. Kadar Phospate. Kadar Alkalinitas (basa). Kadar Hydrazyne (untuk menetralisir air). Bebas dari kesadahan. Kekerasan air boilermenyebabkan timbulnya batubatu yang mengendap dan melekat pada seluruh dinding pipa air.

\section{Bebas dari Keasaman}

Keasaman akan memicu atau meningkatkan air permukaanmaterial menjadi corrosive. 
1. Bebas dari Garam

Garam akan memicu atau meningkatkan air cepat mendidih dan terbentuknya endapan- endapan berupa batu-batu boiler.

2. Bebas dari Gas

Gas $\mathrm{O}_{2}$ dan $\mathrm{CO}_{2}$ akan memicu material corrosive.

3. Harus bersifat Alkalis

\section{a.}

Alkalis dengan konsentrasi normal berkisar antara 9,5-11 dengan menggunakan $\mathrm{PH}$ scale.

\section{Jenis-Jenis Air :}

a. Air Angkasa

Air angkasa akan meresap pada permukaan tanah, tapi banyak sekali pencemaran ketika ada di atmosfer, misalnya berasal dari gas pembuangan pabrik - pabrik Karbondioksida, Karbonmonoksida, Nitrogen dan Amonia, partikel debu, dan mikro organisme.

b. Air Permukaan

Air yang ada di permukaan misalnya danau, sungai dan lain-lain. Air sungai adalah air yang bersumber dari bawah tanah lalu mengalir. Manfaat air sungai bagi

kehidupan sangat besar seperti untuk mengaliri pertanian, dan perikanan.

c. Air Tanah

Chandra, B. (2005). Air yang berada dalam bumi, untuk mendapatkan sumber air tergantung kedalaman tertentu dan sesuai daerahnya. Selain itu, untukmenghisap atau mengalirkan air ke atas permukaan di perlukan pompa.

\section{Sifat-Sifat Air}

Gabriel, (1999). Air bereaksi dengan berbagai substansi membentuk senyawa padat dimana air terikat dengannya, misalnya senyawa hidrat.

* Air dapat terurai menjadi $\mathrm{H}_{2} \mathrm{O} \mathrm{H}^{+}+$ $\mathrm{OH}^{-}$

* Air dapat bereaksi dengan asam kuatdan basa kuat

* Sebagai pelarut
* Titik beku $0^{\circ} \mathrm{C}$

$*$ Titik didih $100^{\circ} \mathrm{C}$

Alaerts dan Sri, S. (1987). PH disebut juga power hydrogen menunjukan konsentrasi ion hydrogen $\left(\mathrm{H}^{+}\right)$di dalam sempel air, PH di ukur untuk mengetahui asam dan basa dari sempel air.

Ion hydrogen $\mathrm{H}^{+}$tidak hanya untuk $\mathrm{H}_{2} \mathrm{O}$ tapi juga terkandung dalamunsur-unsur lainnya (sedikit). $\mathrm{H}^{+}$mempunyai keseimbangan dinamis di dalam air $\left(\mathrm{H}_{2} \mathrm{O}\right)$.

Effendi, H. (2003). Bikarbonat dan karbonat sebagai anion Alkalinitas jika berikatan dengan Kalsium dan Magnesium akan menyebabkan kesadahan. Semakin tinggi nilai Kalsium dan Magnesium semakin tinggi pula nilai kesadahannya.

Pengolahan air umpan boiler ini dilakukan untuk mencegah penurunan kualitas air, terjadinya korosi didalam drum air dan penurunan produksi uap yang mengakibatkan semua unit berjalan tidak maksimal.

\section{METODE}

\section{Penentuan PH pada Air Umpan Boiler.}

Jika PH di bawah standar akan terjadi padatan terlarut akan ikut pada air umpan boiler, sehingga menimbulkan kerak pada pipa boiler, nilai $\mathrm{PH}$ yang rendah akan membuat kekentalan (tegangan permukaan) air boiler menjadi lebih rendah, sehingga padatan-padatan yang terlarut pada airboiler lebih mudah lolos terbawa uap melalui permukaan air. Selain itu PH yang rendah juga membuat kelarutan $\mathrm{Si}$ dalam boiler semakin rendah.

Jika PH di atas standar akan terjadi foaming karena tingginya tegangan permukaan air, sehingga steam sulit terlpas secara porositas dari dalam air. Hal dapat menyebabkan gelembungpada air boiler.

* Causting gouging

Dimana $\mathrm{NaOH}$ yang digunakan untuk menaikkan PH boiler bereaksi dengan besi sehingga menyebabkan korosi. Tingginya $\mathrm{PH}$ terjadi karena pemakaian 
$\mathrm{NaOH}$ secara berlebihan. Berikut reaksi $\mathrm{NaOH}$ dengan besi: $4 \mathrm{NaOH}+\mathrm{Fe}_{3} \mathrm{O}_{4}$ $\rightarrow 2 \mathrm{NaFeO}_{2}+\mathrm{Na}_{2} \mathrm{FeO}_{2}+2 \mathrm{H}_{2} \mathrm{O}$.

Setelah lapisan magnetite $\left(\mathrm{Fe}_{3} \mathrm{O}_{4}\right)$ ini rusak, lebih lanjut $\mathrm{NaOH}$ bereaksi dengan base metal, menyebabkan attack yang di kenalsebagai caustic gouging. $2 \mathrm{NaOH}+\mathrm{Fe}$ $\rightarrow \mathrm{Na}_{2} \mathrm{FeO}_{2}+\mathrm{H}_{2}$.

Daniel, J, Flynn (2009). Keberadaan $\mathrm{H}_{2}$ ini yang selanjutnya bisa menyebabkan hydrogen damage jika lebih lanjutterdifusi ke struktur batas butir metal. Prosedur analisa penentuan $\mathrm{PH}$ pada airumpan boiler mula - mula dimasukkan air umpan boiler ke dalam beaker glas sebanyak $25 \mathrm{ml}, \quad$ yang kemudian menggunakan alat $\mathrm{PH}$ meterlalu bilas elektroda $\mathrm{PH}$ meter denganaquadest di beaker glass hingga bersih dan dikeringkan dengan tissue kemudian celupkan elektroda kedalam sampel uji sampai $\mathrm{PH}$ meter menunjukkan pembacaan yang konstan dan catat hasil pembacaan skala atau angka pada tampilan dari $\mathrm{PH}$ meter.

\section{Penentuan Kesadahan Total}

Prosedur analisa penentuan kesadahan total pada air umpan boiler ialah mula-mula dimasukkan air umpan boiler sebanyak $25 \mathrm{ml}$ ke dalam gelas ukur lalu di masukkan ke. dalam erlenmeyer dengan ditambah $0,5 \mathrm{ml}$ buffer hardness dan 8 tetes Eriochrome Black $T$ (EBT)0,2\%. Selanjutnya di titrasi menggunakan larutan EthylenDiamine Tetra Acetic acid (EDTA) 0,01 M yang sudah di masukan kedalam buret sampai terjadi berubahan warna TAT(Titik Akhir Titrasi) di tandai perubahan warna biru tua, dan catat menggunakan larutan EDTA(ml.. EDTA berfungsi sebagai pengompleks ion $\mathrm{Ca}^{2+}$ dan $\mathrm{Mg}^{2+}$. Titik akhir titrasi terjadi ketikaseluruh ion $\mathrm{Ca}^{2+}$ dan $\mathrm{Mg}^{2+}$ sudah terikat oleh senyawa EDTA. Titik akhir titrasi ditandai dengan perubahan warna merah anggur menjadi warna biru. Metode ini sering digunakan karena mudahdalam menentukan titik titrasi. Prinsip dari kompleksometri yaitu pembentukan ion-ion kompleks dalam larutan.

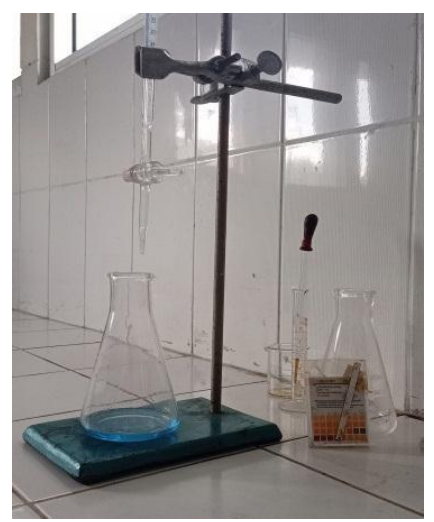

Gambar 1. Proses Titrasi Kesadahan

\section{HASIL DAN PEMBAHASAN}

Hasil yang didapatkan dari analisa PH dan kesadahan, dan pada Air umpan boiler sebagai berikut :

Tabel 1. hasil penelitian PH dan kesadahan

\begin{tabular}{|c|c|c|}
\hline Sampel & $\begin{array}{c}\text { AUMUR 1 } \\
\text { Boiler }\end{array}$ & $\begin{array}{c}\text { SUMUR 2 } \\
\text { Bir Umpan } \\
\text { Boiler }\end{array}$ \\
\hline Tanggal & $25-05-2021$ & $27-05-2021$ \\
\hline PH & 9,40 & 8,90 \\
\hline Kesadahan & $2 \mathrm{ppm}$ & $1,8 \mathrm{ppm}$ \\
\hline
\end{tabular}

Perhitungan mengenai analisa $\mathrm{PH}$, dan pengujian kesadahan pada air umpanboiler.

\section{Perhitungan Analisa PH}

Hasil dari analisa PH didapat dari air yang diproses melalui pengujian dari erlenmeyer yang kemudian menggunakan alat PH meter lalu bilas elektroda $\mathrm{PH}$ meter dengan aquadest di beaker glass hingga bersih dan dikeringkan dengan tissue kemudian celupkan elektroda kedalam sampel uji sampai PH meter menunjukkan pembacaan yang konstan dan catat hasil pembacaan skala atau angka padatampilan dari PH meter. Juga bisa menggunakan kertas indikator PH.

\section{Perhitungan Pengujian Kesadahan \\ Kadar Kesadahan $\left(\right.$ ppm $\left.\mathrm{CaCO}_{3}\right)=$ $1000 \times$ V.EDTA $\times$ M.EDTA $\times 100$ ml sampel}


a. Air Umpan Boiler Sumur 1

Diketahui :

V EDTA : $0,05 \mathrm{ml}$

M EDTA : 0,01 M

V sampel : 25 mlKesadahan (ppm $\left.\mathrm{CaCO}_{3}\right)$

$$
\begin{aligned}
& =\frac{1000 \times V \cdot E D T A \times M . E D T A \times 100}{m l \text { sampel }} \\
& =\frac{1000 \times 0,05 \mathrm{ml} \times 0,01 \mathrm{M} \times 100}{25 \mathrm{ml}} \\
& =2 \mathrm{ppm}
\end{aligned}
$$

b. Air Umpan Boiler Sumur 2

Diketahui :

V EDTA : 0,045 ml

M EDTA: 0,01 M

V sampel: 25 mlKesadahan (ppm $\mathrm{CaCO}_{3}$ )

$$
=\frac{1000 \times V \cdot E D T A \times M \cdot E D T A \times 100}{m l \text { sampel }}
$$

$=\frac{1000 \times 0,045 \mathrm{ml} \times 0,01 \mathrm{M} \times 100}{25 \mathrm{ml}}$

$$
=1,8 \mathrm{ppm}
$$

\section{Pembahasan}

Air boiler yang didapat dari airsumur belum tentu memenuhi standar, untuk itu perlu dilakukan pengolahan dan penelitian untuk mengetahui $\mathrm{PH}$, Kesadahan dan air umpan boiler. Hasil analisa keasaman Feed Water Boiler dari dua sumur diPT. Djarum Kudus Indonesia, masing-masing yaitu 9,40 dan 8,90. Dimana pH dari air sumur 1 di PT. Djarum Kudus Indonesiamasih memenuhi standar SOCPT.Djarum kudus, sedangkan keasaman dari air sumur 2 di PT. Djarum Kudus Indonesia tidak memenuhi standar SOC PT.Djarum Kudus. Untuk mencari konsentrasi kesadahan air larutan standar yang dipakai adalah EDTA (Ethylen Diamine Tetra Acetic acid) 0,01 Molar dengan cara titrasi. Hasilyang didapat dari sumur 1 dan sumur 2 di PT. Djarum Kudus Indonesia masing masing 2 ppm dan 1,8 ppm. Dimana Kesadahan dari air sumur di PT. Djarum Kudus Indonesia telah memenuhi SOC.

\section{KESIMPULAN}

Hasil dari analisa PH pada air umpan boiler dari PT. Djarum Kudus Indonesia, sumur 1 dan sumur 2 masing-masing dari parameter uji air umpan boiler telah memenuhi standar mutu air umpan boiler yang telah ditetapkan SOC, tapi PH dari PT. Djarum Kudus Indonesia Sumur 1 tidak memenuhi standart yaitu 9,40. Karena tingginya $\mathrm{PH}$ tersebut bisa mengakibatkan korosi (karat) pada dinding boiler mengganggu transfer panas dan memperpendek umur alat. Untuk mengatasi di hentikan pemakaian alkali booster dan di lakukan blowdown. Hasil analisa dari penelitian kesadahan pada air umpan boiler dari PT. Djarum Kudus indonesia, dapat diketahui bahwa sumur 1 dan sumur 2 telah memenuhi standar mutu air umpan boiler yang telah ditetapkan SOC di PT.Djarum Kudus.

\section{DAFTAR PUSTAKA}

Alaerts, G dan Santika SS, 1987, Metode Penelitian Air, Usaha Nasional, Surabaya.

Chandra, B. , 2005, Pengantar Kesehatan Lingkungan, Jakarta.

Daniel, J, Flynn, 2009, The Nalco Water Handbook, McGraw- Hill, New York.

Effendi, Hefni, 2003, Telaah KualitasAir : Bagi Pengelola Sumber Daya dan Lingkungan Perairan, Kanisius, Yogyakarta.

Gabriel, J,F, 1999, Fisika Lingkungan, Hiokrates, Jakarta.

Yohana, E dan Askhabulyamin, 2009, Perhitungan Efisiensi dan Konversi dari Bahan Bakar Solarke Gas Pada Boiler Ebara HKL $1800 K A$. 